Ásványi Katalin, Marjainé Szerényi Zsuzsanna, Zsóka Ágnes

\title{
A fenntartható fejlődés feltételeinek megjelenése a nagykörúi lakosság értékrendjében: egy Q-módszeres kutatás eredményei
}

Katalin Ásványi - Zsuzsanna Marjainé Szerényi - Ágnes Zsóka: The appearance of the conditions of sustainable development in the values of the population of Nagykörü: The results of a Qmethodology research

\begin{abstract}
One of the aims of sustainable development is to keep the local communities, to ensure their local welfare, which is essential to eliminate or mitigate negative consequences. In our research, we looked for the answer, how the local population relate to sustainable development. What preferences do they have regarding the place of residence? Do they see any inherent risks, threats? How long horizon they think and what problem solving techniques do they see? How do they think about sustainability issues? The responses were looking for with Q-methodology for which we have defined 46 claims in eight topics: local attachment; local cooperation; willingness to act; management; horizon; threats; solutions The $Q$ methodology handles the respondents into factors, according to which claims they prefer more or less. The results are very well suited to understand the attitudes to the sustainability problems.

Keywords: sustainable development, Q-methodology, values
\end{abstract}

\section{ÖSSZEFOGLALó}

A fenntartható fejlődés egyik célja a helyi közösségek megtartása, helyi boldogulásának biztosítása, amelyhez elengedhetetlen a káros következmények enyhítése vagy kiküszöbölése. Kutatásunk során többek között arra kerestük a választ, hogyan viszonyul a helyi lakosság a fenntartható fejlődéshez. Milyen preferenciákkal rendelkeznek a lakóhelyük megőrzésével, fejlesztésével kapcsolatban, látnak-e különös veszélyeket, fenyegetéseket? Milyen időtávon gondolkodnak és milyen megoldási technikákat látnak a problémákra? Mennyire tartanak szem előtt fenntarthatósági szempontokat? A válaszokat Q-módszerrel kerestük, melyhez 46 állítást fogalmaztunk meg nyolc témakörben: helyi kötődés; helyi együttmúködés; cselekvési hajlandóság; gazdálkodás; időtáv; veszélyek; megoldások. A Q módszer a válaszadókat faktorokba rendezi, aszerint, mely állításokat preferálják jobban, melyeket kevésbé. Az eredmények rendkívül jól alkalmazhatóak a fenntarthatósági problémákhoz való viszonyulások megértéséhez.

Kulcsszavak. fenntartható fejlődés, Q-módszer, értékrend

\section{BEVEZETÉS}

A klímaváltozás számos következménye érinti az emberek mindennapjait, az egyének boldogulását. $A z$ ennek hatására kialakuló szélsőséges vízjárási helyzetek (árvíz, belvíz, aszály) is komoly károkat okozhatnak például a mezőgazdaság vagy a turizmus stb. területén. A fenntartható fejlődés fontos szerepet tölt be a helyi kötődések és együttmúködések kialakulásában, ugyanakkor a károk megelőzésében és az esetlegesen kialakult problémák megoldásában is segítséget nyújt. A lakosság vízigényének változását, a jövőbeli magatartását és elvárásait fókuszcsoportos vizsgálattal (Q-módszerrel) mértük fel. 
Faktorelemzés segítségével az egyes faktorokat jellemeztük az alapján, hogy mely állításoknak adtak az egyének magas és melyeknek alacsony értéket. A Q-módszerrel észleléseket, érzéseket tudunk megragadni. A vízigények számos tényezőtől függnek, köztük a lakosság környezettudatosságától, a helyben maradási hajlandóságuktól, attól, milyen időtávban gondolkodnak. Mindezen tényezők jövőbeli változásainak feltárásához alkalmaztuk a konkrét kistérségi adatokat.

\section{ELMÉLETI HÁTTÉR}

A fenntartható fejlődés fogalmát először az 1987-es Bruntland-jelentésben (Közős jövőnk) ismerhettük meg, azóta pedig számos szerző, köztük magyarok is igyekeztek a definíciót a gyakorlati élethez közelebb hozni, annak érdekében, hogy a jelszavak hangoztatása helyett a mindennapi életünkben is tenni tudjunk jövőnk érdekében. Manapság nagyon gyakran hallható a következő mondat: „Gondolkodj globálisan, cselekedj lokálisan!”. A mondatból arra a következtetésre juthatunk, hogy még a globális problémák elleni védekezésben is a kisebb közösségek, egy ország, egy régió, egy járás, de leginkább egyegy település lakói is rendkívül sokat tehetnek. A nemzetközi környezetpolitika már régóta felismerte a helyi közösségek szerepét a fenntartható fejlődésben, lásd például az EU 6. Környezetvédelmi Akcióprogramját vagy az ENSZ 1992-es Rio de Janeiro-i világkonferenciájának egyik hozadékaként kiadott Agenda 21 elnevezésű dokumentumot [Harangozó - Zilahy, 2012: 45-62]. Az Agenda 21 a fenntartható fejlődés megvalósulásának ad egyfajta keretet az élet minden területére kiterjedően, kitérve a célokra, a szükséges teendőkre általánosan, valamint az intézményi feltételekre, azokra az eszközökre, amelyek a megvalósításhoz szükségesek (pl. a finanszírozás kérdéseire). 28. fejezete külön foglalkozik a helyi fenntarthatósággal, amelyet azóta Local Agenda 21 vagy LA21 néven is ismerünk. Ennek szellemében hazánkban is egyre több településen készül el a Fenntartható Fejlődés Helyi Programja, amelynek alapvető célja az önkormányzat és a lakosság aktív közremúködésével és támogatásával egy olyan program kidolgozása és véghezvitele, amelynek eredményeképpen olyan település alakul ki, ahol a lakosság otthon érzi magát, mindezt úgy, hogy a fenntartható fejlődés elvei érvényesüljenek, vagyis a környezeti és társadalmi folyamatok a gazdasági fejlődésből profitálni tudjanak, a három terület egysége és egyensúlya valósuljon meg [Szlávik - Turchany, 2002: 129]. Tehát a helyi közösségek tagjainak cselekvései, gondolkodásmódja, a jövőjük figyelembevétele elengedhetetlen a globális eredmények eléréséhez. (A globális és a helyi fenntarthatóság közötti kapcsolat egy lehetséges tárgyalását lásd Kocsis [2014: 103114] munkájában.)

Mi szükséges ahhoz, hogy egy helyi közösség fenntartható módon éljen? Nyilván a társadalmunk, a gazdaságunk és a környezetünk is változik, ezért abban kulcsszerepet játszik a reziliencia, magyarul alkalmazkodóképesség, amely alatt a környezet és a társadalom alkalmazkodóképességét is érthetjük. Kerekes [2011: 4-13] megfogalmazta a rugalmas, alkalmazkodni képes társadalmi és ökológiai rendszer jellemzőit, melyek az alábbiak:

- „a diverzitás fenntartása és megőrzésének támogatása (biológiai, tájképi, gazdasági és társadalmi értelemben is),

- az ökológiai sokféleség ember általi "kontrolljának« korlátozása [vö. Kocsis, 2010: 3-52],

- a modularitás tisztelete (a csatlakozó rendszerek jobban viselik a sokkhatást),

- a tanulás, a társadalmi hálózatok és a helyileg kifejlesztett szabályok fontosságának felismerése és hangsúlyozása" [idézi Bándi, 2013: 11191125].

Gyulai [2012: http://www.mtvsz.hu/dynamic/fenntart/a_fen ntarthato_fejlodes.pdf] felhívja a figyelmünket arra, hogy a fenntarthatóság kulturális kérdés, egy viszonyrendszer, amely meghatározza viszonyunkat a környezetünkhöz, társadalmi és 
Ásványi - Marjainé - Szerényi - Zsóka: A fenntartható fejlődés feltételeinek megjelenése ...

természeti környezetünkhöz egyaránt. Érdemes lehet mintegy kulturális beágyazottságként tekinteni a kérdésre, mely témát Kocsis [2002: 209] sajátos emberi gyökerek megléteként vagy hiányaként elemzett.

A helyi lakosság, illetve helyi közösségek fenntartható fejlődéshez való viszonyának vizsgálata azért is kiemelten fontos, mert szorosan kapcsolódik más területek (a vállalati szektor, illetve a teljes gazdaság) fenntarthatóságához [Harangozó, 2008: 38-50]. A tanulmány éppen egy kistérség lakóinak, a nagykörúiek környezetükhöz való viszonyulását kívánja bemutatni, amelyet a Q-módszer alkalmazásával tártunk fel. A kutatást az ún. WateRisk projekt keretében hajtottuk végre, amely 2009-2011 között zajlott azzal a fó céllal, hogy egy, a társadalmi, környezeti változásokat is figyelembe venni tudó, a globális klímaváltozásra válaszoló modellt alakítson ki, elsősorban a szélsőséges vízjárási jelenségeket középpontba állítva, de kitérve a globális éghajlatváltozás lehetséges gazdasági és társadalmi hatásaira is (a projektet az NKTH finanszírozta (TECH-08-A4/2-2008-0169), leírása és eredményei megtalálhatók a következő szakirodalomban: Koncsos (szerk.), 2011). A cikk alapjául szolgáló elemzés széleskörűen, a globális klímaváltozás következményeinek és az azokhoz történő alkalmazkodás módjainak kérdésköreit is vizsgálja a településen élők szemszögéből.

\section{A Q-MÓDSZER MÓDSZERTANI HÁTTERE}

A kutatáshoz az ún. Q-módszert használtuk, amelyet Stephenson fejlesztett ki (Stephenson, 1953) az emberi szubjektivitás szisztematikus vizsgálatának céljából. „A Q-módszert az attitűdök és vélemények szubjektív jellegének hangsúlyossága miatt a kvalitatív módszerek közé sorolják" [Hofmeister-Tóth, 2005: 2], és „elsősorban vélemények, attitűdök/beállítódások, és értékrendszerek felderítésére használják" (id. mú, 3.o.). A módszer elsősorban az angolszász országokban terjedt el [ld. többek között: [Brown, 1996: 561-567; Brown, 1993: 91-138]. Az International Society of Scientific Study of Subjectivity társaság 1985 óta évente rendez Q-konferenciákat, amelyek igen hasznosak az alkalmazási lehetőségek megismerésére, megvitatására.

A Q-módszertan fő célja, hogy egy adott témával kapcsolatos véleményekből típusokat képezzen, amihez kvantitatív elemzési technikákat vesz igénybe. Voltaképpen egy „fordított” faktoranalízist végez, amelynek során nem változókból hoz létre látens változókat, hanem a válaszadók kerülnek faktorokba - ún. véleménycsoportokba véleményük hasonlósága és különbözősége alapján. A módszer kvalitatív jellegét ugyanakkor az adja, hogy nem követel meg a kvantitatív elemzések megbízhatóságához szükséges mintanagyságot, illetve reprezentativitást. A módszer nem alkalmas reprezentatív típusképzésre, csak tipikus véleményformák előállításával segíti a kutatót az alakfelismerésben. A vizsgálatba viszonylag kevés, általában 10-50 személyt vonnak be, akiket meghatározott kritériumok alapján választanak $\mathrm{ki}$. Jellegzetességei miatt a Qmódszer hidat képez a kvalitatív és a kvantitatív kutatási eljárások között, kombinálva mindkét kutatási forma előnyeit [Brown 1996: 561-567]. A Q-módszer speciális adatgyújtési eljárást alkalmaz, az ún. „Q-sort technikát”, amelynek lényege, hogy a kutató kártyákon jelenít meg állításokat, szavakat, esetleg képeket, és a résztvevő személyeknek a véletlenszerüen megszámozott kártyákat kell egymáshoz viszonyítva egy előre megadott skála alapján, egyetértésüknek megfelelően rangsorolni. A vizsgálati személyek először megismerkednek a témával és a kártyákon szereplő állításokkal, majd megkezdődik az osztályozás. A résztvevők először általában három csoportba osztják a kártyákat aszerint, hogy egyetértenek-e a rajta szereplő állítással, nem értenek egyet vele, vagy azok közömbösek számukra. Ezután az értékelő skála kategóriái szerint tovább rangsorolják az állításokat, egymáshoz viszonyítva, minden állítás besorolását külön megfontolva. Az értékelő skála a kártyák számától függően általában $7(-3 \ldots+3), 9(-4 \ldots+4)$, vagy $11(-5 \ldots+5)$ kategóriát tartalmaz.

$\mathrm{Az}$ állítások besorolásának eredményeként kialakul minden egyes vizsgálati személy egyéni 
rangsora, az ún. Q-osztályok. A kiértékelési folyamat során a módszer páronként összehasonlítja a preferencia-sorrendeket (vagyis a Q-osztályokat), és meghatározza azok korrelációját. Eredményként egy ún. interkorrelációs mátrix adódik, amelyből főkomponens vagy centroid módszer segítségével állíthatók elő a faktorok, vagyis azok a tipikus Q-osztályok, amelyek az egyéni vélemények „közös nevezőjét” tartalmazzák.

A faktorokat ezután célszerű egyszerúbb faktorstruktúrába átforgatni - Varimax rotációval vagy kézi rotációval -, mivel így könnyebben értelmezhetővé válik az eredmény. Természetesen mindegyik preferenciasorrendnek köze van mindegyik faktorhoz, de általában az egyes személyek válaszaik alapján többé-kevésbé jól kapcsolhatók valamelyik tipikus Q-osztályhoz. Ez azt jelenti, hogy a módszer az egyébként látens különbségek és hasonlóságok alapján a válaszadókat besorolja a lehető leghomogénebb csoportokba. Az egyéni vélemények így strukturált, statisztikailag jól interpretálható formában jelennek meg. A végeredményként kapott faktorok a nagyon hasonló preferenciasorrenddel rendelkező válaszadókat - illetve azok rangsorait - tartalmazzák.

A Q-módszer tehát „olyan innovatív eljárás a társadalomtudományokban, amely mind a kvantitatív, mind a kvalitatív kutatások kiegészítője lehet" [Brown, 1993: 91-138, idézi: Hofmeister-Tóth, 2005: 12]. Azért kiegészítője, mert kis mintával dolgozik, és nem követeli meg a reprezentativitást, így nem helyettesítheti a reprezentatív felméréseket. „A Q-eljárás különösképpen olyan esetekben alkalmazható, amikor a magatartás nehezen kommunikálható, vagy még nem állnak tudatos standard vélemények és nézőpontok rendelkezésre" [Hofmeister-Tóth, 2005: 12].

A Q-módszer alkalmazásánál kiemelt jelentőséggel bír a rangsorolandó állítások átgondolt megfogalmazása. Ez két szempontból is lényeges. Mivel a vizsgálati személyeknek az állításokat egymással páronként összehasonlítva kell az egyetértési skála különböző értékeihez besorolniuk, ezért az állításokat úgy kell megfogalmazni, hogy egymással összevethetők legyenek, köztük fontossági sorrend felállítható legyen.

A kutatónak a Q-sort technika alkalmazásakor el kell döntenie, hogy „kötött kiosztást”, vagy „nyílt kiosztást” választ. Kötött kiosztás esetén a vizsgálati személyek előre meghatározott számú kártyát sorolhatnak be az értékelési skála egyes kategóriáiba, amivel biztosítják, hogy preferencia-sorrendjük a normálishoz igen közeli, annál kicsit laposabb eloszlást kövessen. Ez a követelmény kevés számú megkérdezett esetén is alkalmassá teszi a módszert az eredmények statisztikai feldolgozására. Kötött kiosztást általában akkor alkalmaznak, amikor a vizsgálati személyek nincsenek teljesen tudatában saját preferenciáinak, így „a szortírozási (döntési) folyamaton keresztül, amelyben a különböző állítások rendezése történik, szilárdul meg saját álláspontjuk" [Hofmeister-Tóth, 2005: 8]. A kötött kiosztásnál ugyanakkor ügyelni kell arra, hogy az állítások rangsorolásával követni lehessen a kívánt lapos normális eloszlást. Túl sok pozitív, vagy túl sok negatív formában megfogalmazott állítás például nehezíti a döntési folyamatot, elveheti a vizsgálati személyek kedvét az osztályozástól, és mindenképpen torzítja az eredményeket.

A páros összehasonlításon alapuló rangsorolásra alkalmas állítások kiválasztását két lépésben végeztük el. A megfogalmazott 46 állítást először kis mintás tesztelésnek vetettük alá, annak ellenőrzése céljából, hogy az állítások alkalmasak-e a vizsgálatra, vagyis a résztvevő személyek képesek-e a 46 állítás egyéni rangsorolására. A lehetséges problémák feltárásával alakítottuk ki ezután a végleges állításokat.

A végleges állításokból álló ún. Q-minta megtervezésénél a strukturáltság kérdése is felmerül. A nem strukturált Q-mintánál az állításokat interjúk, csoportos beszélgetések, vagy hétköznapi vélemények segítségével választják ki. A strukturált Q-minta tervezése ezzel szemben előzetes elméleti megfontolásokon alapul, ahol ugyanannyi állítást rendelnek minden elméleti kategóriához. Az általunk tervezett Q-minta 
Ásványi - Marjainé - Szerényi - Zsóka: A fenntartható fejlődés feltételeinek megjelenése ...

mindenképpen a strukturált megoldáshoz áll közel, mivel alapját előzetes elméleti megfontolások képezik. Az egyes témakörökhöz (a kutatás céljaihoz) ugyanakkor nem pontosan ugyanannyi állítást rendelünk, hanem annyit, amennyit feltétlenül szükségesnek gondolunk az adott témakör jellemzéséhez. Az állítások egyenletes elosztását az állítások száma sem teszi lehetővé.

\section{A FENNTARTHATÓSÁG FELTÉTELEI ÉS A Q-MÓDSZER ÁLLÍTÁSAINAK KAPCSOLATA}

A helyi közösségek a változásokhoz, köztük az éghajlatváltozás következményeihez eltérő módon viszonyulnak. Alkalmazkodóképességük, egyéni habitusuk eltéréseiből fakadóan másmás válasszal reagálnak az eseményekre. A fenntartató fejlődés egyik sokat hangoztatott aspektusa az emberek megtartása eredeti lakóhelyükön. Ebből kifolyólag a kutatás célja az volt, hogy felmérje az árvízzel, belvízzel, illetve aszállyal sújtott területeken élő emberek:

1) kötődését a lakóhelyükhöz: a fenntarthatóság elvei alapján az emberek helyben kell, hogy boldoguljanak, ennek elengedhetetlen feltétele az, hogy szeressék lakóhelyüket, tisztában legyenek a helyi értékekkel, és hosszú távon tudjanak tervezni a megmaradásuk érdekében.

2) hozzáállását a helyi együttműködéshez, integrációhoz, a saját tulajdonhoz, megélhetéshez: fenntartható módon csak akkor tud egy közösség létezni, ha az önérdekeket hajlandóak az emberek háttérbe szorítani akkor, ha a közösségi érdek ezt kívánja.

3) véleményét a gazdálkodási kérdésekkel kapcsolatban: a helyi adottságokra épülő gazdaság megteremtése szintén fontos aspektusa a fenntarthatóságnak, hiszen csak az adott térségre jellemző specifikumokra építve és azok figyelembevételével biztosítható a természeti környezet megőrzése hosszú távon. 4) viszonyulását az őket körülvevő természeti környezethez: mivel társadalmunk és gazdasági tevékenységeink alapját a természet adja, kifejezetten fontos, hogy a helyi adottságokat ismerjék és elismerjék az ott élők, amely szempontokat a mindennapi életükbe is beépítenek. A fenntarthatóság fontos eleme a természeti környezet élő és élettelen elemeinek a védelme, hiszen az élő természet számos hasznot nyújt a társadalom számára, amelyet ökoszisztéma szolgáltatásnak nevez a jelenlegi szakirodalom [Kovács et al., 2011ab: 1-11].

Cél továbbá megismerni az emberek véleményét arról,

5) mit hajlandók személyesen tenni, miben látják a saját, illetve mások felelösségét az általuk fontosnak tartott vízügyi problémákhoz kötődő célok teljesülése, illetve az általuk fontosnak tartott állapotok megőrzése érdekében, így a felelős cselekvés kérdésköre is fontos a fenntartható fejlődés helyi megvalósulásánál.

6) milyen veszélyeket fenyegetéseket érzékelnek a jövőbeli életfeltételeket és helyi természeti állapotot illetően: ezen a téren is elengedhetetlen az ismeretek megléte, a lehetséges következményekre való felkészülés, ugyancsak a helyi adottságokra alapozva.

7) milyen időtávon gondolkodnak: a fenntarthatóság érdekében az általában szokásos rövid távú szemlélet helyett hosszú távú tervezés és cselekvés szükséges.

8) milyen megoldási technikákat látnak a vízzel kapcsolatos, illetve a helyi egyéb problémákra.

A kutatás céljait szándékosan számoztuk meg, mert a felméréshez szükséges állításokat az alábbiakban ezeknek a céloknak megfelelően fogalmaztuk meg.

A kutatás során kialakított 46 állítást a résztvevő személyek egy -5-től +5-ig terjedő skálán értékelték aszerint, mennyire értenek egyet az adott állítással (egymáshoz viszonyítva az állításokat). A kötött kiosztás módszerének megfelelően előre meghatároztuk, hogy a -5-től +5-ig terjedő skála egyes értékeihez hány állítás rendelhető hozzá, hogy a kvázi-normális eloszlás teljesüljön (lásd 1. táblázat).

A válaszokat az ún. „rendezőséma” segítségével kódoltuk, amely az állításokat tartalmazó kártyáknak az előírt kiosztás alapján adódó piramisszerű elrendeződését követi, és amelyre a skála adott értékéhez sorolt állítások sorszámai kerülnek. Ily módon kialakult minden egyes válaszadó preferencia-sorrendje - azaz minden egyes Q-osztály. 


\begin{tabular}{|c|c|c|c|c|c|c|c|c|c|c|}
\hline $\begin{array}{c}-5 \\
(2 \\
\mathrm{db})\end{array}$ & $\begin{array}{c}-4 \\
(3 \mathrm{db})\end{array}$ & $\begin{array}{c}-3 \\
(4 \mathrm{db})\end{array}$ & $\begin{array}{c}-2 \\
(5 \mathrm{db})\end{array}$ & $\begin{array}{c}-1 \\
(6 \mathrm{db})\end{array}$ & $\begin{array}{c}0 \\
(6 \mathrm{db})\end{array}$ & $\begin{array}{c}+1 \\
(6 \mathrm{db})\end{array}$ & $\begin{array}{c}+2 \\
(5 \mathrm{db})\end{array}$ & $\begin{array}{c}+3 \\
(4 d b)\end{array}$ & $\begin{array}{c}+4 \\
(3 \\
\mathrm{db})\end{array}$ & $\begin{array}{c}+5 \\
(2 \\
\mathrm{db})\end{array}$ \\
\hline & & & & & & & & & & \\
\hline & & & & & & & & & & \\
\hline
\end{tabular}

1. táblázat: Az állítások elrendezése a kötött kiosztás alapján

Forrás: Saját szerkesztés

A Q-módszer alkalmazása ezután a már ismertetett módon zajlik, számítógépes program segítségével (A program és a hozzá tartozó használati utasítás letölthető az internetről: $\quad$ http://www.rz.unibwmuenchen.de/ p41bsmk/qmethod/, Peter Schmolck interpretálásában.) A program az egyéni preferencia-sorrendekből (Qosztályokból) hasonlóságuk, illetve különbözőségük alapján tipikus Q-osztályokat (faktorokat) képez.

$\mathrm{Az}$ eredményül kapott Q-minta (vagyis a rangsorolásra kerülő kártyakészlet) állításai témakörök (célok) szerint részletezve az eredményeknél kerülnek bemutatásra.

\section{A KUTATÁS EREDMÉNYEI}

A nagykörúi térségben 39 fő válaszai voltak értékelhetőek a $Q$ módszeres lekérdezésnél. $A z$ itt élő embereket az állításokra vonatkozó preferenciájuk alapján 6 faktorba osztottuk, mivel e faktorszám esetén a variancia értéke már $62 \%$ volt. Az egyes faktorba tartozó személyek létszáma igen változó, jellemzően 5 7 fő, kivétel az 1. és a 3. faktor, ahol 12, illetve 3 fő alkotja az adott faktort. E szélső értékeket az elemzés során fontos figyelembe venni.

\subsection{A helyi kötődés megjelenése a mintában} A helyi kötődéssel kapcsolatban összesen hat állítást fogalmaztunk meg. $\mathrm{Ha}$ az állítások eredményeit áttekintjük, látható, hogy - egyegy kivételtől eltekintve - az egyes állításokhoz hasonlóan álltak hozzá a különböző faktorok tagjai. A térségben az aszály gyakoribb megjelenése miatti elköltözés csupán a 2 . faktorban prioritás, a többi csoportnál ez hátrébb sorolódik, vagyis a többi csoport tagjai kevésbé gondolkodnak ezen a lehetőségen. Ez azért is érdekes, mert a helyi lehetőségekkel való elégedettség, a tisztességes megélhetés lehetőségét inkább a negatív tartományba helyezték, tehát ezzel az állítással nem igazán értettek egyet, amely némi elégedetlenséget takar, ennek ellenére itt kívánnak maradni. Minden klaszternél pozitívan jelent meg a területen élés fontossága, amely állításban az a remény is benne volt, hogy az unokáik is itt maradnak. Igen erős helyi kötődést jelez szinte az összes klaszternél az, hogy a folyót és környékét szívesen használják kikapcsolódásra. Hasonlót, illetve az előző eredménnyel egybehangzót mutat a szabadság alatti elvágyódás állításának eredménye, amely azt mutatja, hogy ez is a kevésbé fontos szempontok közé került. Érdekes, hogy az az állítás, miszerint „örülhet, aki ezen a vidéken él", a pozitív és a negatív tartományba egyaránt bekerült az egyes faktoroknál.

\subsection{Helyi együttmúködés, integráció}

A helyi együttműködést, integrációt jelképező állításokból is összesen hat került a mintába. Az egyes állítások rangsorban elfoglalt helye ebben a kérdéskörben a legtöbb állításnál igen vegyes képet mutat, sokkal kisebb az egyetértés a faktorok között, mint a helyi kötődés állításainál. A helyi termékek preferálása a 2 . faktor kivételével a pozitív oldalon kapott helyet, de általában a közepesen fontosak közé tették ezt az állítást. 
Ásványi - Marjainé - Szerényi - Zsóka: A fenntartható fejlődés feltételeinek megjelenése ...

Nem igazán értettek egyet a válaszadók azzal, hogy a térségben a gazdák a munkában és a bajban is segítik egymást.

Amíg tehát a helyi kötődés általában fontos kérdésként jelenik meg az itt élők számára, addig az emberek közötti kapcsolatokkal már sokkal kevésbé elégedettek (ez azt is jelentheti, hogy a tájhoz, a természethez kötődnek, a társadalmi kapcsolatok azonban sokkal gyengébbek). A legegységesebb képet az az állítás mutatja a faktorok között, amely a megélhetés és a termelés helyi adottságokhoz történő alakításának fontosságát hangsúlyozza, amely minden csoportnál a pozitív oldalra került. A helyiek bevonását a helyi döntésekbe - egy kivétellel -nagyon fontosnak tartják, ráadásul a kialakuló átlagértékek is eléggé közel esnek egymáshoz, vagyis ebben a kérdésben nagy az egyetértés az itt élők között. A következő állítás szerint a falu határa legyen a falubelieké, amellyel közepesen értettek egyet a válaszadók Nagy a megosztottság az etnikai problémák és a térség elnéptelenedésének kérdésében. Három klaszternél a közepesen fontos, pozitív tartományba eső eredményt láthatunk, míg másik háromnál az erősebb egyet nem értés érvényesül, ők tehát nem tekintik problémának az etnikai gondokat, és attól sem tartanak, hogy emiatt a térség lakói máshová költöznének.

\subsection{Gazdálkodási kérdések}

Négy állítást fogalmaztunk meg a gazdálkodással kapcsolatban. Egy állítás kivételével a faktorok közötti különbségek viszonylag nagyok. A legnagyobb egyetértés abban áll, hogy a helyiek nem tartják túlságosan fontosnak, hogy a legmodernebb technológiát alkalmazzák munkájuk során. Ugyanakkor ennek némiképp ellentmond az az eredmény, amely az utolsó állításnál látható: némely faktorban (3., 4.) azt gondolják, a hitel nélkül vásárolt kisebb vagy régi gépekkel olcsóbban és ugyanolyan eredményesen lehet termelni, míg másik részük (2., 6., 1., 5.) ezzel ellentétesen helyezte el az állítást a rangsorban, szerintük ez egyáltalán nem vagy inkább nem igaz. A turizmus fejlesztésének hatásait illetően is vegyes a kép: a 4. faktor tagjai nagyon nem értenek ezzel egyet, míg a 6 . tagjainál már a pozitív tartományban van az eredmény. A hajózás lehetőségei bővítésének térségfejlesztő hatásával kapcsolatban a legegyöntetúbb a közömbösség, sem nem értettek egyet vele, sem nem tartották olyannak, amivel egyáltalán nem tudnak azonosulni. Kivételt az 1 . faktor jelent, tagjai pozitívan értékelték ezt a lehetőséget.

4.4. A résztvevők viszonyulása az őket körülvevő természeti környezethez

A természeti környezethez való viszonyulás körében hét állítást fogalmaztunk meg. Nagyon pozitív az az eredmény, hogy a megkérdezettek egyöntetǔen a fontosabb állítások közé tették azt, hogy a környék óriási természeti értéket képvisel. Természetesen a faktorok között van némi súlyozásbeli különbség. A legtöbb faktornál kiemelkedően jelent meg a környék természetes állapota megőrzésének igénye. A „természet értünk van, minél nagyobb mértékben ki kell használnunk" állítás a fenntarthatóság szempontjából kedvezőtlen, és csak két faktornál jelent meg az egyetértés oldalon. Két faktornál kapott erősebb támogatást a természetes vizek, morotvák fontossága a gazdag élővilág miatt, a többinél vagy gyenge az egyetértés az állítással, vagy gyenge a nem egyetértés, tehát a közömbös tartományban szerepel leginkább. A mesterséges erdő szépségét mindössze egy faktornál találjuk a pozitív oldalon, a többinél a közömböshöz közeli, de negatív érték látszik, az 5. faktor kivételével, amely nagyobb mértékben utasította el ezt az állítást. Az erdők, mint a táj legfontosabb részeinek megóvását és bővítését egy faktor (2.) kivételével mindegyik tagjai inkább a fontos kérdések közé tette. A fenntarthatóság szempontjából kedvező eredmény, hogy a válaszadók a saját területük alatt lévő vizek saját kutakon keresztüli kiaknázását nem tekintik magától értetődőnek.

4.5. Cselekvés, felelősség, feladatok „kiosztása”

Az egyéni cselekvési hajlandóságot, a felelősség vállalását elsősorban vízzel kapcsolatos 
álításokban fogalmaztuk meg, melynek oka, hogy a WateRisk projekt a szélsőséges vízjárás hatásait kívánta vizsgálni

A csapadék és a tavaszi vizek területen tartása érdekében szinte minden faktor tenne valamit, kivételt a 2. csoport tagjai képeznek. Ennek éppen ellentmond, hogy a hely jobb vízgazdálkodása érdekében csak ez a faktor hozna áldozatok is. Erősebb negatív hozzáállás jellemzi azt az állítást, hogy a vízkárok ellen kizárólag állami segítséggel tudnak védekezni, illetve azt is, hogy ez a helyi közösség feladata lenne, ezzel bizonyos mértékig elismerik, hogy a közös cselekvés lehet célravezető. Ugyanezt erősíti annak jelentős hátra sorolása is, hogy mindenkinek saját magának kell megoldania az árvízvédelmi problémákat. A vízügyi problémák megoldása érdekében történő adó kivetését egyik faktor sem fogadja el. Nincs egyetértés abban, hogy kizárólag a szakemberek feladata lenne a folyó és vízrendszerének múködésére vonatkozó kérdések kezelése.

\subsection{Veszélyek, fenyegetések}

Bizonyos mértékig a felelősségtudat megjelenik a veszélyek, fenyegetések címszóval illetett állításokban is. Mindössze egy faktor tagjai értettek egyet azzal, hogy hosszú távon nem veszélyezteti semmi a környék vízellátását. $A$ térség lakói inkább úgy érzik, hogy nem csak külső feltételektől függenek a térség problémái, a közömbös vagy a gyengén nem ért egyet tartományba került ez az állítás. Két faktor szerint elengedhetetlen a mútrágyák, vegyszerek alkalmazása. Az egyéni felelősség jelenlétét jelzi, hogy többségében nem gondolják úgy, hogy a házukat oda építik, ahová akarják, akár még az ártérre is, továbbá az is, hogy az ingatlanok biztosítását is két faktor a fontosabbak közé helyezte. A bankhitelek megítélésénél már nagyobb a különbség: két faktornál erősebb az egyetértés, kettőnél éppen ellentétes válaszok születtek. Egyöntetúen nem értenek egyet abban, hogy a termésre felesleges biztosítást kötni, valamint a faktorok többségében úgy érzik, az emberek nincsenek tisztában az árterek és folyók múködésével, a kockázatok kezelésének lehetőségével.

\subsection{Az időtáv kezelése}

A szemléletmód időtávjának kiderítéséhez összesen két állítás került a Q-mintába. A két állítás közül az első a hosszú távú, míg a második a rövid távú gondolkodást tükrözi. $A z$ eredményekből kiolvashatjuk, hogy a térségben élőknél mindkettő jelen van, viszont a hosszú táv erősebb a rövidnél. Az egyetértés intenzitása ugyan eltérő, de minden faktorban az egyetértés oldalán kapott helyet az az állítás, miszerint akkor is megéri erdőt ültetni, ha a hasznait csak az unokáink élvezhetik. Mindemellett szeretnék élvezni munkájuk rövid távú gyümölcseit is, de ez az álítás minden csoportnál hátrébb került az előzőnél, ami a fenntarthatóság szempontjából pozitív.

4.8. Megoldási lehetőségek a vízzel kapcsolatos problémákra

A megoldási lehetőségeket is elsősorban az árvíz, belvíz problémájával összefüggésben fogalmaztuk meg. Szinte teljes az egyetértés a faktorok között abban (és a különbség elenyésző, egy kivétellel), hogy a csatornahálózat fejlesztése nem csak a belvíz kárait csökkentené, de az öntözési lehetőségeket is javítaná. Minden faktornál az elutasítottak közé került az az állítás, hogy ha ki tud menni a víz az ártérre, akkor több halat lehet fogni. A víz töltés mögötti, mélyfekvésű területeinek víz tározására alkalmazása megosztotta a csoportokat, három inkább egyetért ezzel, míg a másik három inkább elutasította azt. Három faktor erőteljesen támogatta azt, hogy a települések védelmét a gátak magasításával, vésztározók építésével kellene megoldani. Mindössze egy faktor értett markánsabban egyet azzal, hogy tavasszal a területeket mihamarabb ki kell szárítani a termelés érdekében.

\section{A FAKTOROK ÖSSZKÉPE A FENNTARTHATÓSÁG SZEMPONTJÁBÓL}

$A z$ egyes témakörök faktoronkénti vizsgálatát két részre bontottuk, külön értékeltük a pozitiv és a negatív jelentéstartalommal bíró állításokat. A 2. táblázatban + és - jellel jelöltük, hogy az adott faktor hogyan viszonyul az egyes témakörökhöz. 
Ásványi - Marjainé - Szerényi - Zsóka: A fenntartható fejlődés feltételeinek megjelenése ...

$A+$ jel a fenntarthatóság szempontjából megfelelő hozzáállást, a - jel a nem fenntartható viszonyulást jelenti. A jelek számával pedig az attitűd erősségét fejeztük ki, vagyis +++ azt jelenti, hogy a faktor fenntartható módon gondolkodik az adott témakörben.

$\mathrm{Az}$ 1. faktor gondolkodik a leginkább fenntartható módon a megadott témakörökben, azon belül is a veszélyekkel kapcsolatban rendelkezik erős fenntarthatósági hozzáállással. A cselekvés az, amelyet legkevésbé tart fontosnak, ami arra utal, hogy még ez a csoport sem látja át az egyéni felelősség és cselekvés fontosságát. Fontos megemlíteni, hogy ebbe a faktorba koncentrálódott a válaszadók közel egyharmada. A fenntarthatósághoz való igen erős hozzáállásuk alapján jövőorientáltaknak nevezzük őket.

\begin{tabular}{|c|c|c|c|c|c|c|}
\hline Témakör/Faktor & 1. faktor & 2. faktor & 3. faktor & 4. faktor & 5. faktor & 6. faktor \\
\hline helyi kötödés (+) & ++ & +++ & + & + & ++ & + \\
\hline helyi kötödés (-) & + & + & +++ & + & +++ & +++ \\
\hline helyi együttmüködés (+) & ++ & + & -- & ++ & ++ & ++ \\
\hline helyi együttmüködés (-) & ++ & -- & +++ & - & -- & +++ \\
\hline gazdálkodási kérdések (+) & + & -- & ++ & -- & - & - \\
\hline gazdálkodási kérdések (-) & ++ & ++ & - & +++ & +++ & - \\
\hline természeti környezet (+) & ++ & ++ & ++ & + & + & + \\
\hline természeti környezet (-) & ++ & - & + & -- & - & -- \\
\hline cselekvés (+) & -- & -- & + & - & - & -- \\
\hline cselekvés (-) & + & +++ & + & +++ & ++ & - \\
\hline veszélyek (+) & + & + & +++ & - & + & -- \\
\hline veszélyek (-) & +++ & + & ++ & ++ & + & ++ \\
\hline időtáv (+) & +++ & +++ & +++ & ++ & +++ & ++ \\
\hline idötáv (-) & -- & - & - & - & -- & - \\
\hline megoldás (+) & ++ & - & - & ++ & + & - \\
\hline megoldás (-) & + & - & -- & - & ++ & -- \\
\hline
\end{tabular}

2. táblázat: A faktorok értékelése az egyes témakörökben fenntarthatósági szempontból

Forrás: saját szerkesztés

Az 5. faktorba tartozók tekinthetők a második legerősebb csoportnak a fenntartható gondolkodás terén, bár náluk már több helyen is előfordul, hogy nem a fenntarthatósági szempontok alapján sorolják be az állításokat a saját preferencia sorrendjükben. A helyi kötődés számukra az egyik legfontosabb tényező, ugyanakkor a vízzel kapcsolatos problémák megoldását is jól látják, illetve a veszélyeket illetően is fenntartható a hozzáállásuk. A többi témakörben a pozitív és negatív jelentéstartammal bíró állításokat vizsgálva fenntarthatósági szempontból hol jól látják a helyzetet, hol rosszul, nincs egységes, kiforrott véleményük, összességében az értékőrzők elnevezést alkalmazhatjuk rájuk A 3. faktor nagyon hasonlóan gondolkodik, mint az 5. faktor. Számukra is a helyi kötődés igen fontos, illetve szintén jól látják a veszélyeket, ugyanakkor ők a természeti környezetet illetően is egyértelmúen fenntartható módon gondolkodnak. Leginkább a vízzel kapcsolatos 
problémák megoldásában tér el a véleményük az 5. faktortól. Ez a faktor az egyetlen, amelyik a cselekvés témakörben megfogalmazott állítások alapján fenntartható attitűddel rendelkezik. A cselekvők elnevezés illik a faktorra.

A 2. és a 4. faktor az előző háromtól eltérően, de egymáshoz nagyon hasonlóan gondolkodik. Érdekes, hogy ők sorolták leginkább hátra a cselekvéshez kapcsolódó, negatív tartalmú állításokat, vagyis elismerik, hogy közös erőfeszítésre és összefogásra szükség van, viszont az egyéni felelősségvállalás kevésbé fontos a számukra (is). Mivel a 2. faktornál a helyi kötőséhez kapcsolódó állítások kerültek leginkább a pozitív tartományba, ezért őket helyi kötődésúeknek nevezzük. A 4. faktor tagjai eléggé határozottan - de nem feltétlenül fenntarthatóan - foglaltak állást több kérdésben is, ezért őket elképzeléseikhez ragaszkodóknak hívjuk.

A 6. faktor gondolkodik a legkevésbé fenntartható módon, bár a helyi kötődés és együttmúködés szempontjából ez a csoport is a fenntarthatósági elveket követi, de minden egyéb tématerületen vagy fordítva látja a helyzetet, vagy nem egységes a véleménye a pozitív és negatív állítások alapján, ezért őket ambivalenseknek nevezzük. (lásd 3. táblázat)

\begin{tabular}{|c|c|}
\hline Faktor száma & Faktor megnevezése \\
\hline 1. faktor & Jövőorientáltak \\
\hline 2. faktor & Helyi kötődésűek \\
\hline 3. faktor & Cselekvők \\
\hline 4. faktor & Elképzeléseikhez ragaszkodók \\
\hline 5. faktor & Értékőrzők \\
\hline 6. faktor & Ambivalensek \\
\hline
\end{tabular}

3. táblázat: A nagykörǔi térség lakóinak csoportjai

Forrás: Saját szerkesztés

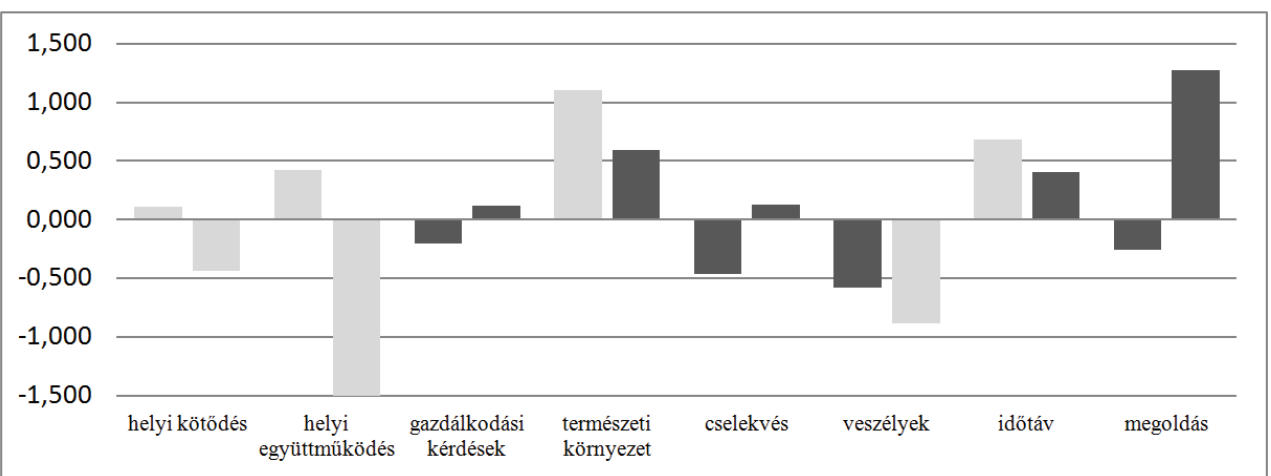

1. ábra: A kitöltők összesített válaszai a pozitív és negatív jelentésű állítások témakörök szerinti értékei alapján

Forrás: saját szerkesztés

\section{KÖVETKEZTETÉSEK, ÖSSZEGZÉS}

A nagykörúi lakosság fenntarthatósághoz való hozzáállásának összképét az összes kitöltő által kialakított sorrend alapján mutatjuk be. $A z$ összes válaszadó preferencia sorrendje alapján a program készít egy összesített sorrendet, melyből az egyes témakörökre vonatkozóan a pozitív és negatív tartalmú állításokhoz tatozó értékeket átlagolva megvizsgáltuk, hogy milyen a kitöltők viszonyulása a területekhez a fenntarthatóság szempontjából. Az 1. ábra szemlélteti ennek eredményét, melyen világos szürkével jelöltük, amennyiben a lakosok 
Ásványi - Marjainé - Szerényi - Zsóka: A fenntartható fejlődés feltételeinek megjelenése ...

hozzáállása a fenntarthatósági szempontoknak megfelelő volt és sötét szürkével, ha azzal pont ellenkezett.

Összességében tehát az állapíthatjuk meg, hogy a nagykörúi lakosság a helyi kötődés és együttmúködés tekintetében egységesen pozitív hozzáállást mutat, az ehhez kapcsolódó állításokat fenntarthatósági szempontból megfelelő helyre helyezték. Szintén egységes, viszont nem fenntartható elveket mutat a vízzel kapcsolatos problémák megoldásával kapcsolatos viszonyulásuk, a gazdálkodási kérdésekhez való hozzáállásuk és az egyéni cselekvési hajlandóságuk. Jellemzően nem érzik az egyéni felelősséget, inkább hárítják másra azt, és jobban hisznek az együttmúködésben. A természeti környezet értékét látják, de ugyanakkor saját céljaikra is felhasználják.
Felismerik, hogy a víz okozta károk igen súlyos következményekkel járhatnak, ugyanakkor annak megelőzéséért mégsem tesznek igazán. Tudják, hogy hosszú távon kell gondolkodni, viszont rövid távon is fontosnak tartják a megtérülést.

A nagykörűi lakosság fenntarthatósághoz kapcsolódó viszonyáról a Q-módszer egy igen átlátható képet mutat. Fel tudtuk mérni, mely témakörökben gondolkodnak fenntartható módon az emberek, és melyek azok, amelyekben nem értenek egyet a fenntarthatósági elvekkel. Jelen tanulmány lehetőséget biztosított a téma feltárására, a későbbiekben azonban szükség lenne további kutatásra is arra vonatkozóan, milyen módon lehetne javítani a lakosság fenntartható gondolkodásán.

\section{IRODALOMJEGYZÉK}

[1.] Bándi Gyula (2013): Hozzászólás a túlélés szellemi kör üzenetéhez egy jogász szemével. Magyar Tudomány, 2013/9. 1119-1125 p. http://epa.oszk.hu/00600/00691/00120/pdf/EPA00691_mtud_2013_09_1119-1125.pdf, letöltés dátuma: 2014. október 10.

[2.] Brown, S.R. (1993): A primer on Q Methodology. In: Operant Subjectivity, 16. 91-138. p.

[3.] Brown, S.R. (1996): Q Methodology and Qualitative Research. In: Qualitative Health Research, 6. 4. 561-567. p.

[4.] Gyulai Iván (2012): A fenntartató fejlődés. Ökológiai Intézet a Fenntartható Fejlődésért Alapítvány, $\quad$ Miskolc. $109 \quad \mathrm{p}$. http://www.mtvsz.hu/dynamic/fenntart/a_fenntarthato_fejlodes.pdf, letöltés dátuma: 2014. október 10.

[5.] Harangozó Gábor (2008): A környezeti teljesítményértékelés módszerei. Vezetéstudomány, 2008/2. szám, 38-50. p.

[6.] Harangozó Gábor, Zilahy Gyula (2012): A civil szervezetek szerepe a vállalatok tevékenységének fenntarthatóbbá válásában. Civil Szemle. 9. évf. 1. szám, 45-62. p. ISSN 1786-3341

[7.] Hofmeister-Tóth, Á. (2002): Application opportunities of Q methodology in marketing research. (In Hung.) Study workshop, Budapest: Corvinus University of Budapest, Department of Marketing Research and Consumer Behavior, 8-12 p.

[8.] Kerekes Sándor (2011): Fenntarthatóság és társadalmi felelősség - A globalizálódó világ megoldatlan problémái. Magyar Bioetikai Szemle. 1, 4-13. p.

[9.] Kocsis Tamás (2002): Gyökereink: Örömről és gazdagságról egy világméretű fogyasztói társadalomban. Budapest: Kairosz, 209 p.

[10.] Kocsis Tamás (2010): Létkérdések - Önkényuralom és népesedés a bioszférában. Kovász 14 (1-4) 3-52. p. 
[11.] Kocsis Tamás (2014): Is the Netherlands sustainable as a global-scale inner-city? Intenscoping spatial sustainability. Ecological Economics 101, 103-114. p.

[12.] Koncsos László (szerk). (2011): Jövőképtől a vízkészlet-kockázatig. BME Vízi Közmű és Környzetmérnöki Tanszék, Budapest, ISBN: 978-963-313-060-5.

[13.] Kovács, E., Kelemen, E., Pataki, Gy. (2011a) Ökoszisztéma szolgáltatások a tudományterületek és a szakpolitikák metszéspontjaiban, Természetvédelmi Közlemények 17: 1-11. p.

[14.] Kovács, E., Pataki, Gy., Kelemen, E., Kalóczkai, Á. (2011b): Az ökoszisztéma-szolgáltatások fogalma a társadalomkutató szemszögéből. Magyar Tudomány 172 (7): 780-787. p.

[15.] Stephenson, W. (1953): The study of behavior: Q-technique and its methodology. Chicago: University of Chicago Press, 479-480. p.

[16.] Szlávik János, Turchany Guy (szerk.) (2002): Útmutató a Fenntartható Fejlődés Helyi Programjai (Local Agenda 21) elkészítéséhez. Készült a Belügyminisztérium megbízásából. $129 \mathrm{p}$.

[17.] http://www.prof-turchany.eu/documents/Helyi_Agenda_21_utmutato.pdf, letöltés dátuma: 2014. október 10. 